\title{
ANALISIS ZAKAT PRODUKTIF TERHADAP INDEKS KEMISKINAN, NILAI MATERIAL DAN SPIRITUAL PARA MUSTAHIK
}

\author{
Nono Hartono \\ Sekolah Tinggi Ekonomi Islam (STEI) Al-Ishlah Cirebon \\ E-mail: khalidbinwalid1435@gmail.com \\ Mohamad Anwar \\ Sekolah Tinggi Ekonomi Islam (STEI) Al-Ishlah Cirebon \\ E-mail: onemohandad@gmail.com
}

\begin{abstract}
The Analysis of Productive Zakat on Poverty Index, Material and Spiritual Value of Mustahik. This research intend to (1) analyze the changes of mustahik household income after receive assistance from productive zakah funds from Cirebon Zakat Center and (2) identify the characteristics of material and spiritual values of mustahik after obtaining assistance from productive zakah funds from the Cirebon Zakat Center based on the CIBEST model. This study uses a quantitative approach with data collection techniques in the form of observation, interviews and filling out questionnaires. The statistical test and data analysis used are paired data $t$ test and CIBEST model. The results of the study showed that mustahik household income after receiving productive zakah funds experienced a significant change. Before the assistance of zakah, the average household income of mustahik are Rp. 1,110,563, and after getting zakah the average household income of mustahik rise to $R p .1,653,000$. This means that there is an increase in the average household income of mustahik by Rp. 542,437. Based on the CIBEST model, the material and spiritual value characteristics of mustahik after assistance productive zakah funds from Cirebon Zakat Center experienced a change. After the assistance, the number of mustahik households in the category of prosperous households (quadrant I) increased by 47.50 percent. Whereas, number of mustahik households that fall into the material poor category (quadrant II) decreased by 25.00 percent. Likewise, the number of mustahik households included in the category of spiritual poor (quadrant III) and absolute poverty (quadrant IV) fell by 54.55 percent and 90.91 percent respectively.
\end{abstract}

Keywords: productive of zakah, poverty, material and spiritual value

Abstrak. Analisis Zakat Produktif Terhadap Indeks Kemiskinan, Nilai Material Dan Spiritual Para Mustahik. Penelitian ini bermaksud mengkaji perubahan pendapatan rumah tangga mustahik setelah mendapatkan bantuan dana zakat produktif dari Zakat Center Thoriqotul Jannah Cirebon dan mengidentifikasi karakteristik nilai material dan spiritual mustahik setelah mendapatkan bantuan dana zakat produktif dari Zakat Center Thoriqotul Jannah Cirebon berdasarkan model 
Islamiconomic: Jurnal Ekonomi Islam Vol.9 No.2 Juli - Desember 2018

CIBEST. Penelitian ini menggunakan pendekatan kuantitatif dengan teknik pengumpulan data berupa observasi, wawancara dan pengisian kuesioner. Adapun uji statistik dan analisis data yang digunakan adalah uji $t$ data berpasangan dan model CIBEST. Hasil penelitian menujukkan bahwa pendapatan rumah tangga mustahik setelah mendapatkan bantuan dana zakat produktif mengalami perubahan yang signifikan. Sebelum adanya bantuan dana zakat, rata-rata pendapatan rumah tangga mustahik adalah Rp 1.110.563 dan setelah mendapatkan bantuan dana zakat rata-rata pendapatan rumah tangga mustahik naik menjadi Rp. 1.653.000. Artinya terjadi peningkatan rata-rata pendapatan rumah tangga mustahik sebesar Rp. 542.437. Berdasarkan model CIBEST, karakteristik nilai material dan spiritual mustahik setelah mendapatkan bantuan dana zakat produktif dari Zakat Center Thoriqotul Jannah Cirebon mengalami perubahan. Setelah adanya bantuan dana zakat, jumlah rumah tangga mustahik yang berada pada kategori rumah tangga sejahtera (kuadran I) mengalami peningkatan sebesar 47.50 persen. Sedangkan jumlah rumah tangga mustahik yang masuk kategori miskin material (kuadran II) menurun 25.00 persen. Begitupun jumlah rumah tangga mustahik yang masuk kategori miskin spiritual (kuadran III) dan miskin absolut (kuadran IV) masing-masing turun sebesar 54.55 persen dan 90.91 persen.

Kata Kunci: zakat produktif, kemiskinan, nilai material dan spiritual.

\section{PENDAHULUAN}

Kemiskinan merupakan salah satu masalah yang bersifat multi dimensional dan dihadapi oleh berbagai negara, khususnya negara-negara berkembang. Multi dimensional dalam hal ini adalah bahwa kemiskinan tidak hanya dapat diukur dalam satu aspek, misalnya hanya diukur dari aspek ekonomi saja, tetapi dapat diukur pula melalui pendekatan kebutuhan spiritual masyarakat. Indonesia sebagai salah satu negara berkembang memiliki bagian masalah kemiskinan yang cukup besar. Tingkat kemiskinan masyarakat walaupun cenderung menurun, namunnyatanya angka kemiskinan yang sudah dicapai saat ini masih jauh dari targetangka kemiskinan Millennium Development Goals (MDGs) atau Deklarasi Milennium. Terdapat delapan target yang disepakati oleh para pemimpin dunia di New York pada tahun 2000 untuk dicapai pada tahun 2015, kedelapan targettersebut meliputi masalah kemiskinan,

pendidikan, kesetaraan gender, angkakematian bayi, kesehatan ibu, beberapa penyakit menular utama, lingkungan serta permasalahan global terkait perdagangan, serta bantuan dan hutang. Oleh karena itu walaupun jumlah penduduk miskin cenderung turun namun masih cukup jauh dari target MDGS yang telah ditargetkan dan disepakati bersama (Laporan MDGs 2008). 


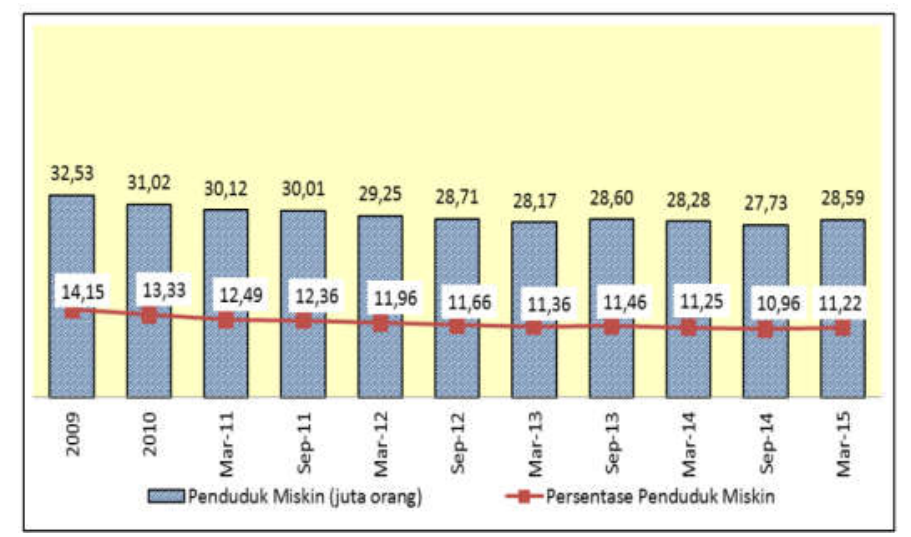

\section{Gambar 1.1 Jumlah dan persentase penduduk miskin di Indonesia periode 2009-2015}

Sumber : BPS (2016)

Badan Pusat Statistik (BPS) mencatat jumlah penduduk miskin per Maret 2015 mencapai 28,59 juta orang atau 11,22 persen dari total penduduk Indonesia. Jumlahnya bertambah 86 ribu orang dalam kurun enam bulan sejak September 2014 yang sebanyak 27,73 juta orang atau 10,96 persen. Mereka adalah penduduk dengan pengeluaran per bulan di bawah garis kemiskinan, berdasarkan Survei Sosial Ekonomi Nasional (Susenas) enam bulanan yang digelar BPS bulan Maret lalu. Badan Pusat Statistik (BPS) mencatat jumlah penduduk miskin per Maret 2015 mencapai 28,59 juta orang atau 11,22 persen dari total penduduk Indonesia. Jumlahnya bertambah 86 ribu orang dalam kurun enam bulan sejak September 2014 yang sebanyak 27,73 juta orang atau 10,96 persen. Mereka adalah penduduk dengan pengeluaran per bulan di bawah garis kemiskinan, berdasarkan Survei Sosial Ekonomi Nasional (Susenas) enam bulanan yang digelar BPS bulan Maret lalu1.

Jumlah penduduk miskin di Provinsi Jawa Barat pada tahun 2014 hingga tahun 2015 mengalami kenaikan sebesar 0.39 persen atau sebanyak 246694 orang. Pada tahun 2014 tercatat jumlah penduduk miskin yang berada di Provinsi Jawa Barat sebanyak 4238960 orang atau sekitar 9.18 persen. Angka tersebut lebih rendah jika dibandingkan dengan jumlah penduduk miskin di Provinsi Jawa Barat tahun 2015 yang berjumlah 4485654 orang atau sekitar 9.57 persen. 
Islamiconomic: Jurnal Ekonomi Islam

Vol.9 No.2 Juli - Desember 2018

\begin{tabular}{clccccc}
\hline Jumlah Penduduk Miskin dan Garis Kemiskinan Kota/Kab Ciayumajakuning \\
\hline & \multicolumn{3}{c}{$\mathbf{2 0 1 4}$} & \multicolumn{2}{c}{$\mathbf{2 0 1 5}$} \\
\cline { 3 - 6 } No & $\begin{array}{c}\text { Kota/ } \\
\text { Kabupaten }\end{array}$ & $\begin{array}{c}\text { Jumlah } \\
\text { Pendudu } \\
\text { k Miskin } \\
\text { (Dlm } \\
\text { ribuan) }\end{array}$ & $\begin{array}{c}\text { Garis Kemiskinan } \\
\text { (Rp/Kapita } \\
\text { /Bulan) }\end{array}$ & $\begin{array}{c}\text { Jumlah } \\
\text { Penduduk Miskin } \\
\text { (Dlm ribuan) }\end{array}$ & $\begin{array}{c}\text { Garis } \\
\text { Kemiskinan } \\
\text { (Rp/Kapita/ } \\
\text { Bulan) }\end{array}$ \\
\hline $\mathbf{1}$ & Kota Cirebon & 30.60 & $349,599.00$ & 31.74 & 358,654 \\
\hline $\mathbf{2}$ & Kab. Cirebon & 300.53 & $312,194.00$ & 313.21 & 327,032 \\
\hline $\mathbf{3}$ & Kab. & 240.68 & $363,360.00$ & 253.12 & 379,080 \\
\hline $\mathbf{4}$ & Indramayu & Kab. Kuningan & 133.03 & $271,015.00$ & 147.21 & 276,154 \\
\hline $\mathbf{5}$ & $\begin{array}{l}\text { Kab. } \\
\text { Majalengka }\end{array}$ & 158.01 & $368,900.00$ & 167.50 & 379,354 \\
\hline
\end{tabular}

Sumber : BPS Provinsi Jawa Barat (2016)

Berdasarkan Tabel 1.1 diatas, terlihat bahwa jumlah penduduk miskin di Kota/Kabupaten di Ciayumajakuning dari tahun 2014 sampai 2015 mengalami peningkatan. Hal tersebut menunjukkan bahwa program-program yang direncanakan pemerintah dalam mengurangi kemiskinan tidak berdampak signifikan. Program yang direalisasikan tidak menyentuh pada akar masalah faktor kemiskinan.

Permasalahan kemiskinan merupakan masalah ekonomi yang sangat erat kaitannya dengan dimensi sosial. Zakat memiliki tiga dimensi yaitu dimensi sosial, dimensi ekonomi, dan dimensi spiritual. Zakat dalam dimensi sosial berupaya untuk menciptakan harmonisasi kondisi sosial masyarakat, sedangkan dalam dimensi ekonomi berupaya untuk menciptakan pertumbuhan ekonomi berkeadilan dengan tujuan meningkatkan kesejahteraan kaum dhuafa. Dimensi spiritual secara personal merupakan implikasi keimanan seseorang terhadap ketentuan Allah subhanahu wa ta'ala, selain itu dalam hubungan dengan dimensi spiritual, zakat juga menjadi instrumen penyucian harta serta mendorong etos kerja umat muslim untuk mencari rezeki yang halal (Beik 2010). Oleh karena itu, zakat sebagai salah satu instrumen moneter dan sosial Islam memiliki peranan yang cukup besar untuk dapat mengatasi masalah kemiskinan melalui program pendayagunaan zakat tersebut. Selain itu, zakat juga erat kaitannya dengan aspek ibadah atau spritual. Sehingga zakat tidak hanya melibatkan aspek sisi finansial saja tetapi juga sisi spiritual. Salah satu program pendayagunaan zakat yang dapat mengentaskan kemiskinan adalah zakat produktif. 
Nono Hartono, dkk.: Analisis Zakat Produktif...

Zakat produktif lebih bersifat jangka panjang, mustahik akan diberikan suatu modal untuk dijadikan usaha yang nantinya diharapkan mampu meningkatkan produktivitas usahanya. Zakat produktif ini akan membuat mustahik lebih mandiri dalam membiayai kehidupannya karena para mustahik akan mendapatkan tambahan penghasilan. Zakat produktif dinilai lebih bermanfaat bagi mustahik dibandingkan dengan zakat konsumtif yang bersifat sesaat. Mustahik diberikan modal dan dibekali tentang managemen usaha, sehingga terbebas dari lingkaran setan kemiskinan.

Zakat Center Thoriqotul Jannah Cirebon merupakan salah satu Lembaga Amil Zakat (LAZ) yang cukup besar dan memiliki rekam jejak yang baik dalam pengumpulan dan pendayagunaan zakat di wilayah III Cirebon (Kota Cirebon, Kabupaten Cirebon, Kabupaten Indramayu, Kabupaten Majalengka dan Kabupaten Kuningan). Zakat Center Thoriqotul Jannah Cirebon didirikan pada tanggal 22 Juli 2003 berdasarkan Keputusan Menteri Kehakiman dan Hak Asasi Manusia Republik Indonesia Nomor C-354. Ht.01.02 Tahun 2004, Akta notaris Hendra Harmen, S.H No. 3 dan direkomendasikan oleh MUI Kota Cirebon No. 33/MUI-UX-2003. Dan pada tahun 2013 lembaga ini telah mendapatkan Sertifikat Manajemen Mutu ISO 9001:2008. Berdasarkan perannya sebagai lembaga resmi pengumpul dana ZISWAF, Zakat Center Thoriqotul Jannah Cirebon berdasarkan data 3 (tiga) tahun penerimaan donasi setiap tahunnya mengalami peningkatan sebagaimana disajikan pada Tabel 1.2 dibawah ini.

Tabel 1.2

Dana Zakat, Infaq/Sedekah dan Wakaf yang dikumpulan Zakat Center Thoriqotul Jannah Cirebon (Tahun 2014 - 2016).

\begin{tabular}{|c|c|c|c|c|}
\hline \multirow{2}{*}{ No } & \multirow{2}{*}{ Sumber Dana } & \multicolumn{3}{|c|}{ Pengumpulan Dana ZISWAF (Rp/Tahun) } \\
\hline & & 2014 & 2015 & 2016 \\
\hline 1 & Zakat & $596,804,013$ & $789,178,592$ & $662,125,050$ \\
\hline 2 & Infaqdan/sedekah & $1,534,723,406$ & $1,422,717,239$ & $2,031,066,953$ \\
\hline 3 & Wakaf & $44,005,000$ & $32,345,000$ & $23,775,000$ \\
\hline 4 & Dana Pengelola & $2,297,789$ & $2,698,593$ & 195,301 \\
\hline 5 & Non Syariah & 77,398 & $(305,251)$ & 390,421 \\
\hline & Jumlah & $2,177,909,620$ & $2,246,636,188$ & $2,717,554,741$ \\
\hline
\end{tabular}

Dari tabel di atas diketahui bahwa penerimaan donasi Zakat Center Thoriqotul Jannah Cirebon dari tahun 2014, 2015 hingga 2016 terus mengalami kenaikan. Pada 
Islamiconomic: Jurnal Ekonomi Islam Vol.9 No.2 Juli - Desember 2018

tahun 2015 penerimaan donasi meningkat 3\% dari tahun 2014 dan pada tahun 2016 meningkat $17 \%$ dari tahun sebelumnya. Peningkatan donasi yang berhasil dihimpun menunjukkan tingginya kepercayaan masyarakat terhadap lembaga pengelola ZISWAF.

Program penyaluran dan pendayagunaan dana zakat oleh Zakat Center Thoriqotul Jannah Cirebon diantaranya terdapat di bidang ekonomi, pendidikan, kesehatan, sosial dan dakwah. Program yang bergerak di bidang produktif yaitu bidang ekonomi, dalam hal ini Program Ekonomi Mandiri (E-Man). Berikut disajikan penyaluran dan pendayagunaan dana zakat. Program tersebut berupaya untuk membantu memecahkan masalah kemiskinan dengan cara mendampingi masyarakat melakukan usaha di bidang-bidang yang telah digeluti oleh para mustahik. Program ini bertujuan agar masyarakat berdaya secara finansial dan spiritual.

Tabel 1.3

Penyaluran dan Pendayagunaan Dana Zakat Tahun 2014 - 2016

\begin{tabular}{|c|c|c|c|c|}
\hline \multirow{2}{*}{ No } & \multirow{2}{*}{ Nama Program } & \multicolumn{3}{|c|}{ Dana Zakat (/Tahun) } \\
\hline & & 2014 & 2015 & 2016 \\
\hline 1 & Ekonomi Mandiri & $143,793,425$ & $79,838,100$ & $148,184,300$ \\
\hline 2 & Cerdas Mulia & $224,647,500$ & $161,931,500$ & $346,013,000$ \\
\hline 3 & Sekolah Binaan & $208,733,300$ & $89,380,700$ & $67,953,100$ \\
\hline 4 & Peduli Ibnu Sabil & 490,000 & 275,000 & 110,000 \\
\hline 5 & Safari Ramadhan & $10,147,500$ & $18,076,000$ & $15,638,500$ \\
\hline & Jumlah & $587,811,725$ & $349,501,300$ & $577,898,900$ \\
\hline
\end{tabular}

Oleh Karenanya, Dalam Program Ini Zakat Center Thoriqotul Jannah Cirebon Tidak Hanya Memberikan Bantuan Dalam Bentuk Dana, Tetapi Juga Dalam Bentuk Bimbingan Dan Pendampingan Terkait Usaha Dan Spiritual. Dana Zakat Terkumpul Tersebut Merupakan Potensi Yang Sangat Besar Untuk Didayagunakan Utamanya Dalam Mempercepat Program Pemerintah Dalam Hal Penurunan Jumlah Penduduk Miskin. Besarnya Potensi Zakat Ini Tidak Sebanding Dengan Laju Penurunan Jumlah Penduduk Miskin, Artinya Ada Suatu Masalah Jarak Antara Besarnya Potensi Dana Zakat Dengan Penurunan Jumlah Penduduk Miskin. Berdasarkan Uraian Tersebut, Dibutuhkan Penelitian Mengenai Dampak Pemberian Zakat Produktif Terhadap Indeks Kemiskinan, Nilai Material Dan Spiritual Para Mustahik. Tujuan Penelitian Ini 
Nono Hartono, dkk.: Analisis Zakat Produktif...

$\overline{\text { Adalah (1) Menganalisis Perubahan Pendapatan Rumah Tangga Mustahik Setelah }}$ Mendapatkan Bantuan Dana Zakat Produktif Dari Zakat Center Thoriqotul Jannah Cirebon Dan (2) Mengidentifikasi Karakteristik Nilai Material Dan Spiritual Mustahik Setelah Mendapatkan Bantuan Dana Zakat Produktif Dari Zakat Center Thoriqotul Jannah Cirebon Berdasarkan Model CIBEST.

\section{PEMBAHASAN}

\section{Pendayagunaan Dana Zakat serta Dampaknya terhadap Ekonomi}

Dana zakat yang terserap oleh Badan atau Lembaga Amil Zakat wajib untuk dapat terdistribusikan dan terdayagunakan dengan baik kepada golongan mustahik. Pendayagunaan dana zakat ini memiliki beberapa tujuan yaitu (Suprayitno 2005) :

1. Memperbaiki taraf hidup. Masyarakat yang hidup dibawah garis kemiskinan menjadi fokus utama pendayagunaan dana zakat untuk meningkatkan taraf hidup masyarakat tersebut. Pendayagunaan dengan tujuan meningkatkan taraf hidup dapat dilakukan dengan memberikan keterampilan dan juga modal untuk melakukan usaha produktif

2. Pendidikan dan beasiswa. Pendidikan dianggap sebagai salah satu pondasi awal yang berperan penting dalam pengentasan kemiskinan. Kondisi sarana dan prasarana yang kurang mendukung terutama yayasan pendidikan Islam yang bersifat swasta, dan kurangnya dana untuk melakukan pengembangan dan pembinaan tenaga pendidik menjadi faktor kunci lambatnya perkembangan dunia pendidikan. Dana zakat dapat disalurkan dalam bentuk bantuan pengembangan infrastruktur dan pengembangan fasilitas pendidikan dan juga dalam bentuk dana bantu biaya sekolah bagi anak-anak.

3. Mengatasi masalah ketenagakerjaan dan pengangguran. Ketenagakerjaan dan pengangguran memiliki porsi yang cukup besar dalam permasalahan ekonomi. Sepanjang Februari hingga Agustus 2014 berjumlah 7.24 juta orang, jumlah ini meningkat 0.09 juta orang dari tahun lalu (BPS 2014). Jumlah ini diprediksi terus meningkat seiring dengan melambatnya pertumbuhan ekonomi. Pendayagunaan dana zakat mengambil peranan penting untuk membuka lapangan pekerjaan baru kepada para pengangguran dengan memberikan pembinaan, permodalan, serta pendampingan untuk suatu usaha. Dengan adanya program tersebut diharapkan mampu mereduksi angka pengangguran yang terjadi.

4. Program pelayanan kesehatan. Masalah pelayanan kesehatan bagi masyarakat miskin khususnya wilayah pedesaan pada umumnya belum merata. Dana zakat dapat dimanfaatkan untuk kesejahteraan umat Islam dalam bentuk pelayanan kesehatan. Program yang dilakukan dapat berupa pendirian poliklinik atau pusat pelayanan 
Islamiconomic: Jurnal Ekonomi Islam Vol.9 No.2 Juli - Desember 2018

kesehatan di pedesaan dan juga membantu menanggung biaya perawatan dan pengobatan kaum mustahik.

5. Panti Asuhan. Upaya menanggulangi anak-anak terlantar seperti anak-anak yatim piatu memiliki kebutuhan dana yang tidak sedikit. Sehingga dana zakat dapat digunakan untuk memberikan bantuan kepada berbagai yayasan yang sudah bergerak dalam menanggulangi anak-anak terlantar seperti panti asuhan, dengan adanya bantuan dana ini program dan daya tampung di panti asuhan tersebut dapat melakukan ekspansi.

6. Sarana peribadatan. Zakat dapat digunakan untuk keperluan pembangunan sarana peribadatan merupakan suatu titik tolak perkembangan pemikiran atas penafsiran kata "fii sabilillah".

Pendayagunaan dana zakat dapat bersifat konsumtif dan produktif bagi mustahik. Pendayagunaan yang bersifat konsumtif merupakan pendayagunaan zakat untuk memenuhi konsumsi pokok kebutuhan yang habis dipakai (Suprayitno 2005). Amil Zakat berupaya untuk tidak memberikan secara langsung dalam bentuk uang, tetapi memberikan dalam bentuk barang atau kebutuhan yang benar-benar dibutuhkan mustahik tersebut, hal ini guna meminimalisir tindak kecurangan dan meningkatkan ketepatan pendayagunaan dana zakat sesuai dengan kebutuhan mustahik. Pendayagunaan dana zakat yang bersifat konsumtif seperti ini secara hukum Islam tidak salah, namun kurang dianjurkan karena pendayagunaan bersifat jangka pendek dan cenderung membuat kondisi mustahik tetap berada pada tingkat kemiskinan yang tidak berubah.

Pendayagunaan zakat yang bersifat produktif merupakan pendayagunaan dalam bentuk pemberian keterampilan produktif dan juga modal kerja. Zakat produktif ini berupaya meningkatkan kemampuan para mustahik, khususnya para fakir dan miskin untuk menciptakan pendapatan dan pengentasan diri dari kemiskinan. Pendayagunaan zakat produktif ini lebih dianjurkan dan diutamakan untuk dilaksanakan karena bersifat jangka panjang dan membuat mustahik lebih aktif untuk melepaskan kondisi kemiskinan yang terjadi pada mustahik tersebut. Zakat memiliki dampak yang baik terhadap perekonomian. Pendayagunaan zakat yang diberikan kepada para mustahik akan meningkatkan pendapatan mustahik tersebut, adanya tambahan pendapatan yang diterima para mustahik akan digunakan untuk membeli berbagai barang dan jasa kebutuhan pokok sehingga meningkatkan permintaan agregat terhadap barang-barang dan jasa-jasa pokok. 
Nono Hartono, dkk.: Analisis Zakat Produktif...

Model CIBEST

Model CIBEST adalah model perhitungan kemiskinan dan kesejahteraan yang didasarkan pada kemampuan pemenuhan kebutuhan material dan spiritual. Yang menjadi isu pokok dalam model ini adalah, bagaimana menetapkan standar kebutuhan material dan kebutuhan spiritual ini, sehingga memudahkan kita dalam menganalisis apakah suatu keluarga atau rumah tangga masuk ke dalam kelompok keluarga sejahtera, keluarga miskin material, keluarga miskin spiritual, maupun keluarga miskin absolut. Dalam konteks pemenuhan kebutuhan material, maka cara menghitung standar garis kemiskinan material, atau yang diistilahkan dengan material value (MV) dilakukan dengan tiga pendekatan. Pertama, melalui survei kebutuhan minimal yang diperlukan oleh suatu keluarga atau rumah tangga, yang didasarkan sekurang-kurangnya pada lima jenis kebutuhan pokok, yaitu sandang, pangan, papan, pendidikan dan kesehatan (Beik 2015).

Kedua, dengan memodifikasi garis kemiskinan BPS, dari standar individu (per kapita) menjadi standar rumah tangga atau keluarga. Modifikasi ini diperoleh dari hasil perkalian antara garis kemiskinan per kapita per bulan versi BPS dengan rata-rata besaran ukuran rumah tangga, dimana rata-rata besaran ukuran keluarga dihitung dengan membagi jumlah total penduduk dengan jumlah rumah tangga di wilayah yang diobservasi. Ketiga, dengan menggunakan standar nishab, atau pendapatan minimal yang terkena kewajiban zakat. Dalam konteks Indonesia, standar nishab yang digunakan standar zakat pertanian. Yaitu, senilai lima ausaq, atau setara $653 \mathrm{~kg}$ gabah atau $524 \mathrm{~kg}$ beras. Kemudian angka tersebut dikalikan dengan harga beras standar di tingkat petani yang telah ditetapkan pemerintah. Misalnya, Inpres No 3/2012 telah menetapkan harga beras di tingkat petani sebesar Rp 6600/kg. Maka, besarnya nishab adalah Rp 3,48 juta/bulan.

Dari ketiga pendekatan di atas, yang paling ideal adalah penggunaan pendekatan pertama. Namun jika pendekatan pertama tidak bisa dilakukan karena sejumlah keterbatasan, seperti keterbatasan anggaran, personil maupun waktu, maka menggunakan pendekatan kedua dan ketiga merupakan langkah alternatif yang dapat digunakan. Adapun standar pemenuhan kebutuhan dasar spiritual didasarkan pada lima variabel, yaitu pelaksanaan shalat, puasa, zakat, lingkungan keluarga dan kebijakan pemerintah. Dari kelima variabel tersebut kemudian ditentukan standar garis kemiskinan spiritual atau spiritual poverty line yang disimbolkan dengan SV. Dipilihnya kelima variabel tersebut dilakukan dengan sejumlah alasan. Pertama, dimasukkannya shalat, puasa dan zakat adalah karena ibadah-ibadah tersebut merupakan kewajiban dasar bagi setiap muslim. Ketidakmampuan melaksanakan ketiganya akan menyebabkan penurunan kualitas keimanan dan kondisi spiritualitas seseorang atau suatu rumah tangga. 
Islamiconomic: Jurnal Ekonomi Islam Vol.9 No.2 Juli - Desember 2018

Kedua, dimasukkannya lingkungan keluarga adalah karena pentingnya peran keluarga dalam membangun lingkungan yang kondusif dalam memenuhi kebutuhan spiritual. Keluarga adalah al-madrasatul ula yaitu tempat pendidikan yang pertama dan utama. Keluarga adalah tempat untuk mengembangkan pendidikan karakter dan akhlak yang paling efektif, karena ia adalah unit terkecil dalam masyarakat. Daya tahan keluarga sangat memengaruhi daya tahan masyarakat dan bangsa secara keseluruhan. Ketiga, dimasukkannya kebijakan pemerintah karena kebijakan ini sangat memengaruhi kondusif tidaknya suasana untuk menjalankan ibadah dan memenuhi kebutuhan spiritual. Tugas pemerintah adalah memberikan rasa aman kepada masyarakat dalam menjalankan ibadahnya tanpa harus disertai kekhawatiran akan munculnya tindakan represif kepada mereka yang mencoba taat beragama.

Selain itu, pemerintah juga bertugas untuk menjaga agar jangan sampai terjadi upaya untuk menistakan dan melecehkan ajaran agama sehingga berpotensi menciptakan konflik sosial yang bersifat destruktif. Karena itu, persepsi keluarga terhadap peran pemerintah dalam memberikan suasana aman beribadah merupakan hal yang layak untuk dicermati karena bisa memengaruhi kemampuan mereka dalam memenuhi kebutuhan spiritualnya. Selanjutnya, dilakukan scoring terhadap kelima variabel tersebut sehingga diperoleh nilai skor spiritual rata-rata keluarga (SS). Skala skor yang diberikan berkisar antara 1 sampai 5 , dimana skor 1 mencerminkan kondisi spiritual terburuk, dan skor 5 mencerminkan kondisi spiritual terbaik. Misalnya, skor variabel shalat. Skor 5 adalah ketika setiap anggota keluarga melaksanakan shalat wajib rutin berjamaah dan disertai dengan shalat-shalat sunnah.

Skor 4 adalah melaksanakan shalat wajib rutin tapi tidak selalu berjamaah. Skor 3 adalah melaksanakan shalat wajib tapi tidak rutin. Artinya, kadang-kadang meninggalkan shalat wajib dengan sengaja. Skor 2 menolak dan tidak percaya dengan konsep shalat, dan skor 1 adalah melarang orang lain shalat.Disebut miskin spiritual ketika skor shalatnya adalah 3 atau lebih rendah dari 3.Hal ini karena skor 3 mencerminkan "keberanian" seseorang untuk meninggalkan secara sengaja sebagian shalat wajib, seperti tidak shalat subuh dan isya. Tentu secara spiritual ini akan melemahkan iman dan memiskinkan jiwa. Dengan konsep ini, maka nilai SV adalah sama dengan 3. Setelah diketahui nilai MV dan SV, maka kemudian keluarga yang diobservasi dimasukkan ke dalam kuadran CIBEST. Kuadran 1 atau kuadran sejahtera adalah ketika pendapatannya di atas nilai MV dan nilai SS-nya di atas nilai SV. Kuadran 2 (kemiskinan material) adalah ketika pendapatan lebih kecil atau sama dengan MV dan nilai SS di atas SV. Kuadran 3 (kemiskinan spiritual) adalah ketika pendapatan di atas nilai MV dan nilai SS lebih kecil atau sama dengan nilai SV. Terakhir, 
Nono Hartono, dkk.: Analisis Zakat Produktif...

kuadran 4 (kemiskinan absolut) adalah ketika pendapatan dan nilai SS lebih kecil atau sama dengan nilai MV dan SV. Setelah itu baru dihitung nilai indeks masing-masing kuadran.

\section{Metode Penelitian}

Untuk jenis dan sumber data dibagi menjadi dua bagian, yaitu data primer dan data sekunder. Data primer diperoleh dengan cara pengisian kuisioner dan wawancara dengan para mustahik penerima dana bantuan zakat yang dikelola oleh Zakat Center Thoriqotul Jannah Cirebon. Sedangkan data sekunder diperoleh dari data-data dan dokumen-dokumen yang sudah ada di Zakat Center Thoriqotul Jannah Cirebon dan literatur-literatur lainnya seperti buku, jurnal, skripsi, website resmi, dan lain sebagainya.

Sementara populasi sampel dalam penelitian ini adalah mustahik mitra binaan aktif

Zakat Center Thoriqotul Jannah Cirebon pada program Ekonomi Mandiri (E-Man) yang berjumlah 150 orang. Penarikan sampel dalam penelitian ini dilakukan dengan menggunakan teknik purposive sampling yaitu dengan menentukan sendiri kriteria sampel yang akan dijadikan responden dalam penelitian. Kriteria sampel yang ditentukan oleh peneliti adalah mustahik yang telah menerima bantuan zakat produktif lebih dari 2 (dua) kali. Dari jumlah tersebut populasi 150 orang tersebut, mustahik yang telah menerima bantuan zakat produktif lebih dari 2 kali berjumlah 120 orang. Berdasarkan data tersebut, jumlah sampel yang akan terlibat dalam penelitian ini berjumlah 40 mustahik. Perhitungan jumlah tersebut didasarkan rumus Slovin :

$$
n=\frac{N}{1+N\left(a^{2}\right)}=\frac{120}{1+120\left(0.013^{2}\right)}=40 \text { orang mustahik }
$$

$$
\begin{aligned}
& \text { Keterangan: } \\
& \mathrm{N}=\text { populasi } \\
& \mathrm{n}=\text { sampel } \\
& \alpha=\text { tingkat error }
\end{aligned}
$$

Dalam menganalisis data, Indeks kemiskinan yang digunakan dalam menentukan kondisi rumah tangga mustahik adalah indeks kemiskinan Islami Center of Islamic Business and Economics Studies (CIBEST) Institut Pertanian Bogor (IPB) yang dikembangkan pada tahun 2015 oleh Beik dan Arsyianti (2015). Sedangkan untuk melihat perubahan yang terjadi pada pendapatan rumah tangga mustahik maka analisis yang digunakan adalah dengan menggunakan uji t berpasangan.

Perhitungan yang digunakan sebagai dasar perhitungan dalam penelitian ini adalah nilai dari Material Value (MV) atau garis kemiskinan rumah tangga dan 
Islamiconomic: Jurnal Ekonomi Islam

Vol.9 No.2 Juli - Desember 2018

pendapatan rumah tangga per bulan. Material Value (MV) digunakan untuk mengukur standar minimal material yang harus dipenuhi oleh rumah tangga. Nilai MV diperoleh dengan mengalikan harga barang dan jasa yang dikonsumsi (Pi) dengan jumlah minimal barang dan jasa yang dibutuhkan (Mi).

Secara matematis, MV dapat dirumuskan sebagai berikut:

$$
M V=\sum_{i=1}^{n} P_{i} M i
$$

Keterangan:

MV = Standar minimal material yang harus dipenuhi oleh rumah tangga (Rp atau mata uang lain) atau bisa disebut Garis Kemiskinan Material

$\mathrm{Pi} \quad=$ Harga barang dan jasa (Rp atau mata uang lain)

$\mathrm{Mi} \quad=$ Jumlah minimal barang dan jasa yang dibutuhkan

Perhitungan garis kemiskinan diperoleh dengan mengalikan garis kemiskinan perkapita per bulan dengan rata-rata besaran ukuran rumah tangga. Rata-rata besaran ukuran rumah tangga didapat dari rasio total penduduk dengan jumlah rumah tangga di wilayah yang diteliti (Tsani 2010).

Garis kemiskinan spiritual atau Spiritual Value (SV) diperoleh beradasarkan indikator kebutuhan spiritual dan pemenuhan lima variabel yang menentukan skor spiritual. Lima variabel tersebut adalah ibadah shalat, zakat, puasa, lingkungan rumah tangga dan kebijakan pemerintah. Untuk menilai skor dari variabel-variabel tersebut digunakan skala Likert 1-5. Nilai SV lebih kecil atau sama dengan 3 maka rumah tangga tersebut dapat dikategorikan ke dalam kategori miskin spiritual. Nilai SV diperoleh dengan cara sebagai berikut:

$$
H i=\frac{V p+V f+V z+V h+V g}{5}
$$

Keterangan:

$\mathrm{Hi}=$ Skor aktual anggota rumah tangga ke-i

$\mathrm{Vp}=$ Skor shalat

$\mathrm{Vf}=$ Skor puasa

$\mathrm{Vz}=$ Skor zakat dan infak

$\mathrm{Vh}=$ Skor lingkungan kerja

$\mathrm{Vg}=$ Skor kebijakan pemerintah 
Nono Hartono, dkk.: Analisis Zakat Produktif...

Setelah melakukan perhitungan SV dan MV maka rumah tangga dapat dikategorikan kedalam kuadran CIBEST sebagai berikut:

Tabel 3.2 Kombinasi Aktual MV dan SV

\begin{tabular}{ccc}
\hline $\begin{array}{c}\text { Skor } \\
\text { Aktual }\end{array}$ & $\leq$ Nilai MV & $>$ Nilai MV \\
\hline$>$ Nilai SV & Kaya spiritual, Miskin material & Kaya spiritual, kaya material (Kuadran \\
& (Kuadran II) & I) \\
$\leq$ Nilai SV & Miskin spiritual, miskin material & Miskin spiritual, kaya material (Kuadran \\
& (Kuadran IV) & III) \\
\hline
\end{tabular}

Sumber : Beik dan Arsyianti (2015)

Tabel di atas dapat dijelaskan sebagai berikut:

1. Kuadran I: Jika nilai aktual skor spiritual rumah tangga (SH) lebih besar dari SV dan pendapatannya lebih besar dari MV.

2. Kuadran II: Jika nilai SH lebih besar dari SV dan pendapatan lebih rendah dari MV.

3. Kuadran III: Jika nilai SH lebih kecil dari SV dan pendapatan lebih besar dari MV.

4. Kuadran IV: Jika nilai SH lebih kecil dari SV dan pendapatan lebih kecil dari MV.

\section{Indeks Kesejahteraan}

Indeks kesejahteraan (W) digunakan untuk melihat rumah tangga yang masuk kedalam kuadran I. Pada kuadran ini, rumah tangga dapat dikatakan sejahtera. Nilai W dapat diperoleh dengan formula:

$$
W=\frac{w}{N}
$$

\section{Keterangan:}

$\mathrm{W} \quad=$ Indeks kesejahteraan; $0 \leq \mathrm{W} \leq 1$

$\mathrm{w} \quad=$ Jumlah keluarga sejahtera (kaya secara material dan spiritual)

$\mathrm{N} \quad=$ Jumlah populasi rumah tangga yang diobservasi

\section{Indeks Kemiskinan Material}

Indeks kemiskinan material (Pm) digunakan untuk melihat rumah tangga yang berada pada kuadran II atau miskin material. Nilai indeks kemiskinan material dapat diperoleh dengan formula:

$$
P_{m}=\frac{M p}{N}
$$

Keterangan:

$\mathrm{Pm}=$ Indeks kemiskinan material; $0 \leq \mathrm{Pm} \leq 1$

$\mathrm{Mp} \quad=$ Jumlah keluarga yang miskin secara material namun kaya secara spiritual 


\section{$\mathrm{N}=$ Jumlah populasi (rumah tangga yang diamati)}

\section{Indeks Kemiskinan Spiritual}

Indeks kemiskinan spiritual (Ps) digunakan untuk melihat rumah tangga yangmasuk ke dalam kategori kuadran III atau kategori miskin spiritual. Nilai Ps dapat diperoleh dengan formula:

$$
P_{s}=\frac{S_{p}}{N}
$$

Keterangan:

Ps $=$ Indeks kemiskinan spiritual; $0 \leq$ Ps $\leq 1$

$\mathrm{Sp}=$ Jumlah keluarga yang miskin secara spiritual namun berkecukupan secara material

$\mathrm{N}=$ Jumlah populasi total rumah tangga yang diamati

\section{Indeks Kemiskinan Absolut}

Indeks kemiskinan absolut $(\mathrm{Pa})$ digunakan untuk melihat rumah tangga yang berada pada kuadran IV atau miskin absolut. Nilai Pa dapat diperoleh dengan formula:

Keterangan:

$$
P a=\frac{A p}{N}
$$

$\mathrm{Pa}=$ Indeks kemiskinan absolut; $0 \leq \mathrm{Pa} \leq 1$

Ap = Jumlah keluarga yang miskin secara spiritual dan juga material

$\mathrm{N}=$ Jumlah populasi total rumah tangga yang diamati

\section{Uji t-statistik Data Berpasangan}

Uji $\mathrm{t}$ atau $t$ Test digunakan untuk melihat perubahan yang terjadi pada pendapatan rumah tangga mustahik sebelum dan sesudah adanya bantuan dana zakat. Uji t dilakukan dengan menggunakan perangkat lunak SPSS.

Hipotesis dalam uji ini adalah:

- H0: Pendapatan rumah tangga mustahik setelah adanya bantuan dana zakat tidak berbeda nyata pada taraf $\alpha=5$ persen terhadap pendapatan rumah tangga mustahik sebelum adanya bantuan dana zakat.

- H1: Pendapatan rumah tangga mustahik setelah adanya bantuan dana zakat berbeda nyata pada taraf $\alpha=5$ persen terhadap pendapatan rumah tangga mustahik sebelum adanya bantuan dana zakat. 
Nono Hartono, dkk.: Analisis Zakat Produktif...

\section{PEMBAHASAN}

\section{Analisis Dampak Pendayagunaan Dana Zakat Terhadap Rata-rata Pendapatan Rumah Tangga Mustahik}

Hasil dari pengolahan data pendapatan rumah tangga mustahik dengan uji tstatistik berpasangan, menunjukkan bahwa pendapatan mustahik setelah menerima zakat berbeda (alfa 0,05) dengan pendapatan mustahik sebelum menerima zakat, seperti yang disajikan pada Tabel 2.2 dibawah ini. Artinya bahwa zakat berpengaruh signifikan meningkatkan pendapatan mustahik.

\section{Tabel 4.1}

\section{Hasil Uji t}

\begin{tabular}{|c|c|c|c|c|c|c|c|c|}
\hline & \multicolumn{5}{|c|}{ Paired Differences } & \multirow{3}{*}{$t$} & \multirow{3}{*}{ df } & \multirow{3}{*}{$\begin{array}{l}\text { Sig. } \\
(2- \\
\text { tailed })\end{array}$} \\
\hline & \multirow{2}{*}{ Mean } & \multirow{2}{*}{$\begin{array}{c}\text { Std. } \\
\text { Deviation }\end{array}$} & \multirow{2}{*}{$\begin{array}{l}\text { Std. Error } \\
\text { Mean }\end{array}$} & \multicolumn{2}{|c|}{$\begin{array}{l}95 \% \text { Confidence Interval of the } \\
\text { Difference }\end{array}$} & & & \\
\hline & & & & Lower & Upper & & & \\
\hline $\begin{array}{cc}\text { Pair } 1 & \begin{array}{c}\text { Sebelum zakat - } \\
\text { Setelah zakat }\end{array}\end{array}$ & $5.42438 \mathrm{E}+05$ & 277047.53 & 43805.06128 & $-6.31042 E+05$ & $-4.53833 E+05$ & -12.383 & 39 & .000 \\
\hline
\end{tabular}

Sumber: data primer diolah (2017)

Berikut ini akan dijelaskan mengenai dampak dari pendayagunaan dan pendistribusian dana zakat produktif terhadap perubahan pendapatan rumah tangga mustahik:

Tabel 4.2 Rata-Rata Perubahan Pendapatan Mustahik

\begin{tabular}{lccc}
\hline & $\begin{array}{c}\text { Rata-rata pendapatan } \\
\text { sebelum adanya bantuan } \\
\text { dana zakat (Rp) }\end{array}$ & $\begin{array}{c}\text { Rata-rata pendapatan } \\
\text { setelah adanya bantuan } \\
\text { dana zakat (Rp) }\end{array}$ & $\begin{array}{c}\text { Perubahan } \\
\text { rata-rata } \\
\text { (Rp) }\end{array}$ \\
\hline $\begin{array}{l}\text { Pendapatan rumah } \\
\text { tangga mustahik }\end{array}$ & 1.110 .563 & 1.653 .000 & 542.437 \\
\hline
\end{tabular}

Sumber: data primer diolah (2017)

Berdasarkan tabel di atas maka dapat dapat diambil kesimpulan bahwa pendistribusian dan pendayagunaan dana zakat memiliki dampak terhadap pendapatan rumah tangga mustahik. Dampak yang ditimbulkan oleh pendistribusian dan pendayagunaan zakat adalah dampak yang positif. Hal ini dapat dilihat dari adanya peningkatan rata-rata pendapatan rumah tangga mustahik sebelum dan sesudah adanya bantuan dana zakat. Sebelum adanya bantuan dana zakat yang 
Islamiconomic: Jurnal Ekonomi Islam Vol.9 No.2 Juli - Desember 2018

diberikan oleh Zakat Center Thoriqotul Jannah Cirebon rata-rata pendapatan rumah tangga mustahik secara keseluruhan sebesar Rp. 1.110.563,- dan setelah mendapatkan bantuan dana zakat, rata-rata pendapatan rumah tangga mustahik secara keseluruhan naik menjadi Rp. 1.653.000,-. Artinya terjadi peningkatan ratarata pendapatan rumah tangga mustahik sebesar Rp. 542.437,-.

Untuk melihat dampak dari pendistribusian dan pendayagunaan dana zakat sebagai pengurang tingkat kemiskinan dilakukan dengan menggunakan analisis kuadran CIBEST dan perhitungan indeks kemiskinan. Kedua analisis ini dilakukan dengan melihat dampak sebelum dan sesudah adanya bantuan dana zakat yang diberikan oleh Zakat Center Thoriqotul Jannah Cirebon. Jika terdapat perubahan terhadap rumah tangga mustahik, perubahan baik atau buruk, maka dapat dikatakan bahwa pemberian bantuan dana zakat kepada mustahik memberikan dampak terhadap perubahan tingkat kemiskinan. Baik buruknya perubahan tersebut dapat dilihat dari perubahan indeks kemiskinan yang meliputi indeks kemiskinan absolut, indeks kemiskinan spiritual, indeks kemiskinan material, dan indeks kesejahteraan.

\section{Analisis Kuadran CIBEST pada Tingkat Kemiskinan Rumah Tangga Mustahik Sebelum Adanya Bantuan Dana Zakat}

Sebelum membahas penentuan kuadran CIBEST terhadap tingkat kemiskinan rumah tangga mustahik, terlebih dahulu dihitung tingkat nilai material (material value/MV) pada rumah tangga mustahik berdasarkan wilayah tempat tinggal yaitu Kota Cirebon, Kabupaten Cirebon dan Kuningan. Hasil perhitungan nilai MV mustahik disajikan pada Tabel 2.4 dibawah ini. Berdasarkan perhitungan MV, rumah tangga mustahik yang pendapatannya dibawah Rp. 1,184,450. 32,- tergolong ke dalam rumah tangga miskin.

Tabel 4.3

Hasil Perhitungan Nilai MV

\begin{tabular}{lccccc}
\hline Kab/Kota & $\begin{array}{c}\text { Jumlah } \\
\text { Penduduk } \\
\text { (jiwa) }\end{array}$ & $\begin{array}{c}\text { Rumah } \\
\text { tangga } \\
\text { (RT) }\end{array}$ & $\begin{array}{c}\text { Garis } \\
\text { kemiskinan } \\
\text { (Rp) }\end{array}$ & $\begin{array}{c}\text { Rata-rata besar } \\
\text { ukuran rumah } \\
\text { tangga }\end{array}$ & $\begin{array}{c}\text { Material Value } \\
\text { (MV) } \\
\text { (per RT/bulan) }\end{array}$ \\
\hline Kuningan & $1,055,400$ & 282,603 & 276,154 & 3.735 & $1,031,314.86$ \\
Cirebon & $2,126,200$ & 580,862 & 327,032 & 3.660 & $1,197,074.22$ \\
Kota Cirebon & 307,500 & 80,983 & 358,654 & 3.797 & $1,361,850.56$ \\
\hline
\end{tabular}


Nono Hartono, dkk.: Analisis Zakat Produktif...

$\begin{array}{llllll}\text { Rata-rata } & 1,163,033 & 314,816 & 320,613 & 3.694 & 1,184,450.32\end{array}$

Sumber : Data BPS Provinsi Jawa Barat diolah

Kuadran CIBEST terdiri atas empat kuadran, yaitu kuadran I adalah kategori sejahtera, kuadran II adalah kategori miskin material, kuadran III adalah kategori miskin spiritual, dan kuadran IV adalah kategori miskin absolut. Beradasarkan data yang sudah dikumpulkan melalui kuisioner dan wawancara dengan mustahik, maka didapatkan hasil sebagaimana disajikan pada Gambar 2.1. Beradasarkan data yang diperoleh, terdapat 6 rumah tangga mustahik yang masuk kedalam kuadran I atau masuk dalam kategori sejahtera. Kategori sejahtera ini terletak pada sumbu positif baik pada sumbu garis kemiskinan spiritual maupun pada sumbu garis kemiskinan material. Artinya, 6 rumah tangga mustahik ini sudah tercukupi kebutuhan material dan kebutuhan spiritualnya sebelum mendapatkan bantuan dana zakat dari Zakat Center Thoriqotul Jannah Cirebon.

Selanjutnya pada kuadran II dapat dilihat rumah tangga yang masuk dalam kuadran ini atau masuk dalam kategori miskin material berjumlah 12 rumah tangga. Kuadran II berada pada posisi sumbu negatif pada garis kemiskinan material dan sumbu positif pada garis kemiskinan spiritual. Artinya, rumah tangga tersebut sudah mampu memenuhi kebutuhan spiritualnya namun belum mampu memenuhi kebutuhan materialnya. Rumah tangga pada kuadran ini adalah rumah tangga yang diutamakan dalam menerima bantuan dana zakat. Tujuannya adalah agar rumah tangga tersebut dapat memenuhi kebutuhan materialnya.

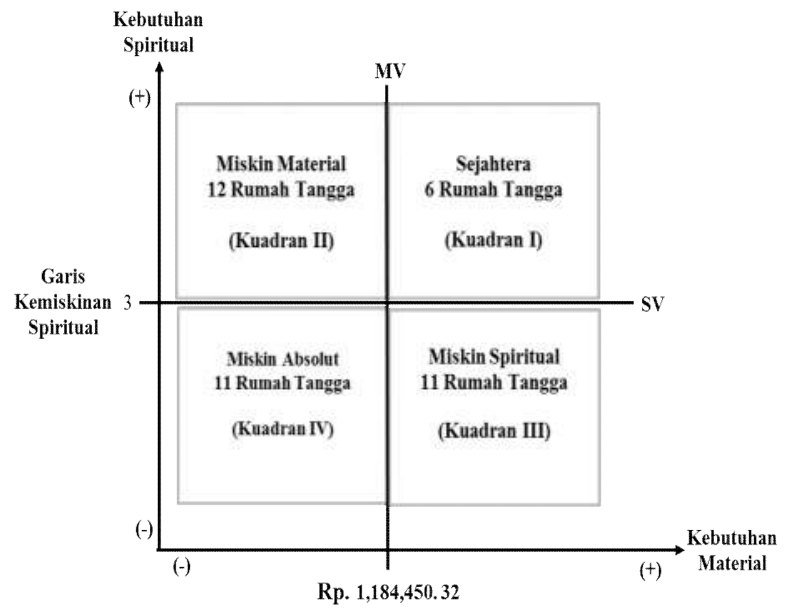

Gambar 4.1 Kuadran CIBEST Sebelum Adanya Bantuan Dana Zakat

Sumber: data primer diolah (2017) 
Pada kuadran III, terdapat 11 rumah tangga yang tergolong dalam kuadran ini. Kuadran ini berada pada posisi sumbu negatif pada garis kemiskinan spiritualnya dan sumbu positif pada garis kemiskinan materialnya. Rumah tangga yang masuk dalam kuadran ini dapat dikatakan sebagai rumah tangga yang miskin spiritual. Artinya, rumah tangga ini sudah mampu memenuhi kebutuhan materialnya tetapi belum mampu memenuhi kebutuhan spiritualnya.

Kuadran terakhir adalah kuadran IV. Jumlah rumah tangga yang masuk dalam kuadran ini berjumlah 11 rumah tangga. Kuadran ini berada pada posisi sumbu negatif baik pada garis kemiskinan spiritual maupun garis kemiskinan material. Rumah tangga yang masuk dalam kuadran ini dapat dikatakan sebagai rumah tangga yang miskin absolut. Artinya, rumah tangga tersebut belum mampu memenuhi kebutuhan spiritualnya maupun kebutuhan materialnya.

\section{Analisis Kuadran CIBEST pada Tingkat Kemiskinan Rumah Tangga Mustahik Setelah Adanya Bantuan Dana Zakat}

Bantuan dana zakat yang diberikan oleh Zakat Center Thoriqotul Jannah Cirebon kepada mustahik diharapkan mampu meningkatkan jumlah rumah tangga mustahik yang masuk dalam kuadran I atau masuk dalam kategori sejahtera. Selain itu, bantuan dana zakat ini juga diharapkan mampu menurunkan jumlah rumah tangga mustahik yang termasuk dalam kategori miskin material, miskin spiritual, dan miskin absolut. Berikut adalah hasil analisis kuadran CIBEST terhadap tingkat kemiskinan rumah tangga mustahik setelah adanya bantuan dana zakat yang diberikan oleh Zakat Center Thoriqotul Jannah Cirebon:

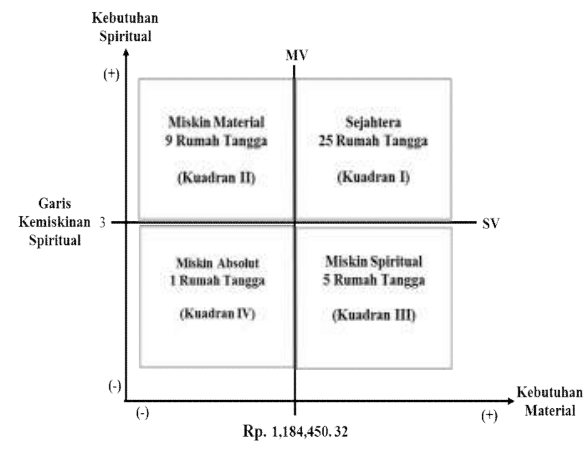

Gambar 4.2 Kuadran CIBEST Setelah Adanya Bantuan Dana Zakat

Sumber: data primer diolah (2017) 
Nono Hartono, dkk.: Analisis Zakat Produktif...

Berdasarkan gambar di atas, rumah tangga yang masuk dalam kuadaran I atau masuk dalam kategori keluarga sejahtera berjumlah 25 rumah tangga, artinya sebanyak 25 rumah tangga mustahik sudah mampu memenuhi kebutuhan spiritual maupun kebutuhan materialnya. Sedangkan rumah tangga yang masuk dalam kuadran II atau miskin material berjumlah 9 rumah tangga. Sebanyak 5 rumah tangga masuk dalam kuadran III atau miskin spiritual dan rumah tangga yang masuk dalam kuadran IV atau miskin absolut berjumlah 1 rumah tangga.

Setelah menganalisis kondisi rumah tangga mustahik sebelum dan sesudah adanya bantuan dana zakat yang diberikan oleh Zakat Center Thoriqotul Jannah Cirebon dengan menggunakan kuadran CIBEST, dapat dilihat terjadi perubahan jumlah rumah tangga pada masing-masing kuadran. Perubahan tersebut dapat dilihat pada tabel berikut:

Tabel 4.4

Perubahan Jumlah Rumah Tangga Mustahik Sebelum dan Sesudah Bantuan Zakat

\begin{tabular}{lcc}
\hline \multirow{2}{*}{ Kuadran } & \multicolumn{2}{c}{$\begin{array}{c}\text { Jumlah Rumah Tangga } \\
\text { Mustahik (orang) }\end{array}$} \\
\cline { 2 - 3 } & Sebelum & Sesudah \\
\hline Kuadran I (Sejahtera) & 6 & 25 \\
Kuadran II (Miskin Material) & 12 & 9 \\
Kuadran III (Miskin Spiritual) & 11 & 5 \\
Kuadran IV (Miskin Absolut) & 11 & 1 \\
\hline
\end{tabular}

Sumber: data primer diolah (2017)

Berdasarkan tabel di atas, dapat dilihat bahwa terjadi perubahan jumlah pada masing-masing kuadran. Pada kuadran I, perubahan yang terjadi pada rumah tangga mustahik yang masuk dalam kategori rumah tangga sejahtera mengalami peningkatan setelah adanya bantuan dana zakat. Sebelum adanya bantuan dana zakat, rumah tangga mustahik yang masuk dalam kuadran I berjumlah 6 rumah tangga. Setelah adanya bantuan dana zakat, jumlah rumah tangga mustahik yang berada pada kuadran I mengalami peningkatan menjadi 25 rumah tangga.

Rumah tangga mustahik yang berada pada kuadran II atau kategori miskin material mengalami penurunan. Sebelum adanya bantuan dana zakat, jumlah rumah tangga mustahik yang berada pada kuadran II atau rumah tangga yang mampu 
Islamiconomic: Jurnal Ekonomi Islam

Vol.9 No.2 Juli - Desember 2018

mencukupi kebutuhan spiritualnya tetapi belum mampu memenuhi kebutuhan materialnya berjumlah 12 rumah tangga. Namun setelah adanya bantuan dana zakat, jumlah rumah tangga yang masuk dalam kuadran II mengalami penurunan menjadi 9 rumah tangga.

Jumlah rumah tangga mustahik yang masuk dalam kudran III atau ketegori miskin spiritual juga mengalami penurunan. Sebelum adanya bantuan dan zakat, rumah tangga mustahik yang masuk dalam kuadran III atau rumah tangga yang mampu memenuhi kebutuahan materialnya tetapi belum mampu memenuhi kebutuhan spiritualnya berjumlah 11 rumah tangga. Namun setelah adanya bantuan dana zakat, rumah tangga mustahik yang masuk dalam kategori miskin spiritual atau kuadran III mengalami penurunan menjadi 5 rumah tangga.

Kuadran terakhir adalah kuadran IV. Kuadran ini menggambarkan kondisi rumah tangga yang berada pada kondisi miskin absolut. Artinya rumah tangga tersebut belum mampu memenuhi kebutuhan material maupun spiritualnya. Sebelum adanya bantuan dana zakat, rumah tangga mustahik yang berada pada kuadran IV berjumlah 11 rumah tangga. Jumlah tersebut mengalami penurunan menjadi 1 rumah tangga setelah adanya bantuan dana zakat.

Berdasarkan analisis yang sudah dilakukan, secara umum adanya bantuan dana zakat yang diberikan oleh Zakat Center Thoriqotul Jannah Cirebon dapat meningkatkan jumlah rumah tangga mustahik yang masuk dalam kuadran I atau dapat dikatakan rumah tangga yang sejahtera. Bantuan dana zakat produktif yang diberikan oleh Zakat Center Thoriqotul Jannah Cirebon juga mampu menurunkan jumlah rumah tangga yang masuk dalam kategori miskin material, miskin spiritual dan miskin absolut. Dengan begitu, dapat ditarik kesimpulan bahwa pendistribusian dan pendayagunaan dana zakat produktif berpengaruh dan berdampak pada turunnya tingkat kemiskinan rumah tangga mustahik.

\section{Analisis Indeks Kemiskinan Islami}

Indeks kemiskinan Islami yang terdapat dalam model CIBEST terdiri atas indeks kesejahteraan, indeks kemiskinan material, indeks kemiskinan spiritual, dan indeks kemiskinan absolut. Berdasarkan hasil analisis kuadran CIBEST, telah diketahui jumlah rumah tangga yang masuk dalam masing-masing kategori. Melalui hasil dari 
Nono Hartono, dkk.: Analisis Zakat Produktif...

kuadran CIBEST tersebut maka akan didapatkan hasil dari perhitungan indeks kemiskinan Islami. Berikut adalah hasil perhitungan indeks kemiskinan Islami.

Tabel 4.5

Indeks Kemiskinan Islami

\begin{tabular}{lccc}
\hline \multicolumn{1}{c}{ Indeks Kemisinan } & $\begin{array}{c}\text { Sebelum adanya } \\
\text { bantuan dana zakat }\end{array}$ & $\begin{array}{c}\text { Setelah adanya bantuan } \\
\text { dana zakat }\end{array}$ & $\begin{array}{c}\text { Perubahan } \\
\text { (Persen) }\end{array}$ \\
\hline Indeks kesejahteraan & 0.150 & 0.625 & 47.50 \\
Indeks kemiskinan material & 0.300 & 0.225 & $(-25.00)$ \\
Indeks kemiskinan spiritual & 0.275 & 0.125 & $(-54.55)$ \\
Indeks kemiskinan absolut & 0.275 & 0.025 & $(-90.91)$ \\
\hline
\end{tabular}

Sumber: data primer diolah (2017)

\section{Analisis Indeks Kesejahteraan Rumah Tangga Mustahik}

Indeks kesejahteraan menggambarkan jumlah rumah tangga mustahik yang masuk dalam kategori rumah tangga sejahtera. Untuk mengetahui dampak dari pendistribusian dan pendayagunaan dana zakat terhadap kesejahteraan rumah tangga mustahik maka penelitian dilakukan sebelum dan sesudah adanya bantuan dana zakat. Beradasarkan data diatas, jumlah rumah tangga mustahik yang berada pada kategori rumah tangga sejahtera mengalami peningkatan dari 0.150 menjadi 0.625. Artinya terjadi peningkatan indeks kesejahteraan rumah tangga mustahik sebesar 47.50 persen. Hasil tersebut menunjukan bahwa dengan adanya pendistribusian dan pendayagunaan dana zakat terbukti dapat meningkatkan indeks kesejahteraan rumah tangga mustahik.

\section{Analisis Indeks Kemiskinan Material Rumah Tangga Mustahik}

Indeks kemiskinan material menggambarkan jumlah rumah tangga mustahik yang masuk dalam kategori miskin secara materialnya namun kaya secara spiritual. Analisis indeks kemiskinan material terhadap rumah tangga mustahik dilakukan sebelum dan sesudah adanya bantuan dana zakat yang diberikan oleh Zakat Center Thoriqotul Jannah Cirebon. Berdasarkan dari penelitian yang sudah dilakukan, diperoleh hasil bahwa terjadi penurunan indeks kemiskinan material pada rumah tangga mustahik. Sebelum adanya bantuan dana zakat, rumah tangga mustahik yang masuk dalam kategori miskin material sebesar 0.300 atau sebesar 30.0 persen. Namun setelah adanya bantuan dana zakat, rumah tangga mustahik yang masuk 
Islamiconomic: Jurnal Ekonomi Islam

Vol.9 No.2 Juli - Desember 2018

dalam kategori miskin material menjadi 0.225 atau 22.5 persen atau mengalami penurunan sebesar 25.00 persen. Artinya, bantuan dana zakat yang diberikan kepada rumah tangga mustahik mampu menurunkan indeks kemiskinan material.

\section{Analisis Indeks Kemiskinan Spriritual Rumah Tangga Mustahik}

Indeks kemiskinan spiritual menggambarkan jumlah rumah tangga mustahik yang masuk ke dalam kategori miskin secara spiritual tetapi kaya secara material. Analisis indeks kemiskinan spiritual rumah tangga mustahik dilakukan sebelum dan sesudah adanya bantuan dana zakat yang diberikan oleh Zakat Center Thoriqotul Jannah Cirebon. Berdasarkan data diatas, indeks kemiskinan spiritual rumah tangga mustahik sebelum dan sesudah adanya bantuan dana zakat mengalami penurunan. Sebelum adanya bantuan dana zakat, rumah tangga mustahik yang masuk dalam kategori miskin spiritual sebesar 0.275 atau sebesar 27.5 persen. Setelah adanya bantuan dana zakat, rumah tangga mustahik yang masuk dalam kategori miskin spiritual turun menjadi 0.125 atau 12.5 persen. Artinya, jumlah rumah tangga mustahik yang masuk dalam kategori miskin spiritual mengalami penurunan sebesar 54.55 persen setelah adanya bantuan dana zakat. Dengan begitu, terbukti bahwa dengan adanya bantuan dana zakat dapat menurunkan indeks kemiskinan spiritual pada rumah tangga mustahik.

Dapat dilihat indeks kemiskinan spiritual rumah tangga mustahik setelah mendapatkan bantuan dana zakat dan bimbingan dari Zakat Center Thoriqotul Jannah Cirebon, nilai indeks kemiskinan spiritual semakin mendekati nol yang artinya semakin rendah tingkat kemiskinan spiritual yang terjadi pada rumah tangga mustahik. Secara umum dapat dikatakan pula pemberian dana zakat dan bimbingan yang diberikan oleh Zakat Center Thoriqotul Jannah Cirebon berpengaruh dalam menurunkan tingkat kemiskinan spiritual rumah tangga mustahik.

Menurunnya indeks kemiskinan spiritual ini menurut persepsi rumah tangga mustahik disebabkan oleh adanya ceramah-ceramah atau materi-materi bimbingan yang mengarah kepada urusan ibadah, walaupun materi mengenai ibadah tidak secara rutin selalu dijalankan. Sebagian besar rumah tangga mustahik dalam penelitian ini pada kondisi sebelum menerima dana zakat produktif dan juga bimbingan sebenarnya sudah tidak masuk dalam kategori miskin spiritual. Hal ini 
Nono Hartono, dkk.: Analisis Zakat Produktif...

terlihat dari skor rata-rata kebutuhan spiritual rumah tangga mustahik sebelum dan setelah mendapatkan bantuan dana zakat produktif dan bimbingan yang disajikan pada Tabel 2.7 dibawah ini:

Tabel 4.6

Skor Kebutuhan Spiritual

\begin{tabular}{|c|c|c|}
\hline \multirow{2}{*}{ Variabel Indikator } & \multicolumn{2}{|c|}{$\begin{array}{l}\text { Skor Rata-Rata Kebutuhan Spiritual } \\
\text { Mustahik }\end{array}$} \\
\hline & $\begin{array}{c}\text { Sebelum } \\
\text { Bantuan Zakat }\end{array}$ & $\begin{array}{c}\text { Setelah Bantuan } \\
\text { Zakat }\end{array}$ \\
\hline Shalat & 3.08 & 3.93 \\
\hline Puasa & 2.90 & 3.80 \\
\hline $\begin{array}{l}\text { Zakat } \\
\text { Lingkungan Rumah Tangga }\end{array}$ & $\begin{array}{l}3.53 \\
3.05\end{array}$ & $\begin{array}{l}4.03 \\
3.23\end{array}$ \\
\hline Kebijakan Pemerintah & 2.95 & 3.50 \\
\hline Rata-Rata Skor & 3.10 & 3.70 \\
\hline
\end{tabular}

Sumber : Data primer diolah (2017)

Skor spiritual mustahik sebelum menerima bantuan zakat sebesar 3.10. Angka tersebut menggambarkan bahwa rata-rata rumah tangga mustahik sudah memiliki nilai spiritual value diatas tiga atau dapat dikatakan rata-rata rumah tangga mustahik sudah tercukupi dalam hal kebutuhan spiritual. Namun tetap variabel spiritual yang memiliki nilai spiritual value dibawah tiga. Setelah adanya bantuan dana produktif dan bimbingan, skor rata-rata kebutuhan spiritual rumah tangga meningkat menjadi 3.70. Hal ini menandakan bahwa rata-rata rumah tangga mustahik semakin baik dalam hal beribadah, seperti telah dijelaskan sebelumnya bahwa menurut persepsi mustahik, bahwa materi-materi bimbingan yang bersifat spiritual juga mempengaruhi kondisi spiritual mustahik. Peningkatan skor rata-rata kebutuhan spiritual ini juga telah dikompensasi oleh menurunnya indeks kemiskinan spiritual rumah tangga mustahik yang telah dijelaskan sebelumnya.

\section{Analisis Variabel Kemiskinan Spiritual}

Mustahik yang mendapatkan bantuan dana zakat produktif harus mengikuti pembinaan dan pendampingan yang dilakukan oleh Zakat Center Thoriqotul Jannah Cirebon. Para mustahik akan diberikan bimbingan, baik terkait dengan bimbingan wirausaha dan juga spiritual. Sebulan sekali para mustahik diharuskan mengikuti pembinaan rutin. Setiap musathik diberikan kesempatan untuk menyampaikan dan 
Islamiconomic: Jurnal Ekonomi Islam

Vol.9 No.2 Juli - Desember 2018

bertanya mengenai hal apapun. Dari sisi bimbingan secara spiritual, mustahik diberikan pemahaman tentang ibadah-ibadah wajib seperti shalat, puasa, manfaat zakat, kewajiban-kewajiban sebagai muslim, usaha yang baik dan halal, dan lain-lain.

Bimbingan yang diberikan oleh Zakat Center Cirebon sejalan dengan kebutuhan spiritual yang dibutuhkan. Berdasarkan wawancara melalui kuesioner yang dilakukan terhadap mustahik, mayoritas mustahik merasakan adanya perubahan terkait perilaku spiritual mustahik tersebut setelah adanya pembinaan spiritual, walaupun secara langsung hal tersebut tidak dapat dikatakan seutuhnya sebagai pembinaan spiritual. Mayoritas mustahik mengalami peningkatan dalam sisi kebutuhan spiritual mulai dari shalat, puasa, zakat dan infak, lingkungan rumah tangga serta kebijakan pemerintah.

\section{Shalat}

Variabel indikator shalat rumah tangga mustahik pada saat belum menerima bantuan dana zakat dan bimbingan spiritual dari Zakat Center Thoriqotul Jannah Cirebon memiliki skor rata-rata sebesar 3.08, angka ini memang berada diatas garis kemiskinan spiritual namun angka ini cenderung mendekati tiga. Artinya skor ratarata rumah tangga mustahik untuk variabel shalat sangat dekat dengan batas garis kemiskinan spiritual. Hal ini dapat dikatakan pula bahwa mayoritas rumah tangga mustahik sudah menjalankan ibadah shalat lima waktu secara rutin namun masih terdapat beberapa rumah tangga mustahik yang belum menjalankan ibadah shalat lima waktu secara rutin. Setelah mendapatkan bantuan dana zakat serta bimbingan spiritual dari Zakat Center Thoriqotul Jannah Cirebon skor rata-rata variabel indikator sholat rumah tangga mustahik meningkat sebesar 0.85 menjadi 3.93 atau meningkat sebesar 20.86 persen. Skor rata-rata variabel indikator sholat mendekati empat artinya semakin banyak rumah tangga mustahik yang melaksanakan sholat lima waktu secara rutin.

\section{Puasa}

Variabel selanjutnya yaitu variabel indikator puasa rumah tangga mustahik pada saat belum menerima bantuan dana zakat serta bimbingan spiritual dari Zakat Center Thoriqotul Jannah Cirebon memiliki skor rata-rata sebesar 2.90 atau sebesar 234 
Nono Hartono, dkk.: Analisis Zakat Produktif...

78.84 persen. Hal ini menandakan bahwa mayoritas rumah tangga mustahik sudah melaksanakan ibadah puasa wajib tidak secara penuh pada bulan Ramadhan. Setelah mendapatkan bimbingan spiritual skor variabel indikator puasa rumah tangga mustahik meningkat sebesar 0.90 menjadi 3.80 atau secara persentase naik 23.68 persen.

\section{Zakat dan Infak}

Selanjutnya, variabel indikator zakat dan infak rumah tangga mustahik sebelum mendapatkan bantuan dana zakat dan bimbingan dari Zakat Center Thoriqotul Jannah Cirebon memiliki skor rata-rata sebesar 3.53. Skor ini menandakan mayoritas rumah tangga mustahik sudah membayar infak minimal sekali dalam setahun namun skor ini dirasa masih cukup rendah karena mendekati batas skor minimal yaitu tiga. Skor rata-rata rumah tangga mustahik dalam hal zakat dan infak meningkat setelah adanya bantuan zakat dan bimbingan. Skor rata-rata meningkat sebesar 0.50 menjadi 4.03. Hal ini menandakan bahwa jumlah rumah tangga mustahik yang membayar infak dan zakat meningkat, bahkan mayoritas rumah tangga mustahik juga membayar zakat harta. Meningkatnya skor ini selain dipengaruhi oleh bimbingan yang diberikan, Zakat Center Thoriqotul Jannah Cirebon juga mengarahkan dan menganjurkan mitra binaan atau mustahik untuk berinfak setiap hari. Anjuran untuk berinfak ini melatih kegemaran berinfak bagi rumah tangga mustahik. Program untuk meningkatkan kegemaran berinfak bagi para mustahik ini sesuai dengan anjuran dalam Al-Qur'an dimana orang yang kurang mampu juga dianjurkan untuk berinfak, sebagaimana firman Allah dalam Al Qur'an di surat Ali-Imran ayat 134:

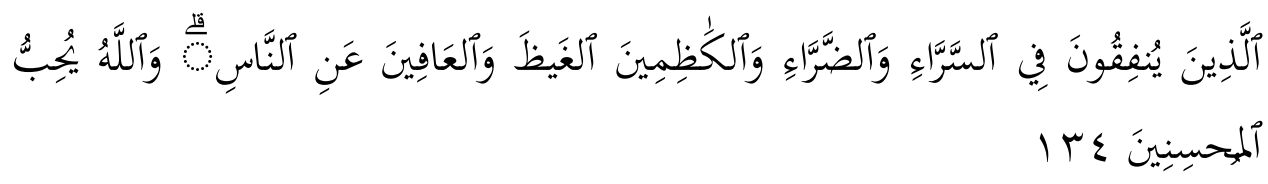

"(yaitu) orang-orang yang berinfak baik diwaktu lapang maupun sempit, dan orang-orang yang menahan amarahnya dan memaafkan (kesalahan) orang lain. Dan Allah mencintai orang yang berbuat kebaikan" 
Islamiconomic: Jurnal Ekonomi Islam

Vol.9 No.2 Juli - Desember 2018

Dalam surat tersebut sangat jelas menggambarkan bahwa berinfak dapat pula dilakukan dalam kondisi sempit, sehingga kemiskinan tidak dapat dijadikan alasan untuk tidak berinfak.

\section{Lingkungan Rumah Tangga}

Variabel ini berupaya menggambarkan kondisi lingkungan keluarga mustahik dalam hal mendukung terpenuhinya kebutuhan spiritual dalam rumah tangga mustahik tersebut. Skor rata-rata untuk variabel lingkungan keluarga sebelum mendapatkan bantuan dana zakat dan bimbingan sebesar 3.05. Artinya mayoritas rumah tangga mustahik masih menganggap ibadah adalah urusan pribadi masingmasing anggota rumah tangga tetapi mulai mengarah kepada mendukung ibadah anggota keluarga. Skor rata-rata variabel lingkungan rumah tangga setelah adanya bantuan dana zakat dan bimbingan dari Zakat Center Thoriqotul Jannah Cirebon meningkat sebesar 0.18 menjadi 3.23. Artinya setelah adanya bantuan dana zakat dan bimbingan dari Zakat Center Thoriqotul Jannah Cirebon mayoritas sudah mendukung ibadah anggota keluarga dalam suatu rumah tangga mustahik, selain itu setelah adanya bantuan dana zakat dan bimbingan skor rata-rata variabel lingkungan rumah tangga mendekati empat. Dapat dikatakan bahwa selain mendukung ibadah masingmasing anggota keluarga, mayoritas keluarga mustahik juga mengarah kepada mendukung ibadah secara bersama-sama.

\section{Kebijakan Pemerintah}

Variabel terakhir yang menjadi indikator kebutuhan spiritual rumah tangga mustahik adalah variabel kebijakan pemerintah. Variabel ini berupaya menggambarkan dukungan pemerintah setempat terhadap upaya pemenuhan kebutuhan spiritual rumah tangga mustahik. Pemerintah disini meliputi pejabat lingkungan setempat sampai pada taraf kelurahan dalam hal mendukung kegiatan peribadatan warga. Skor rata-rata rumah tangga mustahik sebelum adanya bantuan dana zakat dan bimbingan dari Zakat Center Thoriqotul Jannah Cirebon sebesar 2.95. Artinya mayoritas kebijakan pemerintah di lingkungan rumah tangga mustahik masih menganggap ibadah adalah urusan pribadi masyarakat. Pemerintah tidak terlalu banyak mengintervensi atau membuat kebijakan yang berkaitan dengan ibadah 
Nono Hartono, dkk.: Analisis Zakat Produktif...

rumah tangga mustahik. Skor rata-rata rumah tangga mustahik setelah adanya bantuan dana zakat dan bimbingan meningkat sebesar 0.55 menjadi 3.50. Artinya mayoritas rumah tangga mustahik setelah adanya bantuan dana zakat dan bimbingan didukung oleh kebijakan pemerintah seperti meningkatkan sarana dan prasarana ibadah dilingkungan rumah tangga mustahik. Para mustahik bersama dengan lembaga amil zakat sesudah adanya bantuan dana zakat dan pembinaan dan bimbingan, lebih pro aktif dalam mengaspirasikan hal-hal yang berkaitan dengan kebutuhan spiritual yang dibutuhkan.

\section{Analisis Indeks Kemiskinan Absolut Rumah Tangga Mustahik}

Indeks kemiskinan absolut menggambarkan jumlah rumah tangga mustahik yang masuk ke dalam kategori miskin secara material maupun secara spiritual. Rumah tangga pada kategori ini belum mampu mencukupi kebutuhan spiritualnya maupun kebutuhan materialnya. Analisis indeks kemiskinan absolut terhadap rumah tangga mustahik dilakukan sebelum dan sesudah adanya bantuan dana zakat yang diberikan oleh Zakat Center Thoriqotul Jannah Cirebon. Berdasarkan tabel diatas, indeks kemiskinan absolut sebelum dan sesudah adanya bantuan dana zakat mengalami perubahan. Sebelum adanya bantuan dana zakat, indeks kemiskinan absolut rumah tangga mustahik bernilai 0.275 atau sebesar 27.5 persen. Setelah adanya bantuan dana zakat, indeks kemiskinan absolut rumah tangga mustahik turun menjadi 0.025 atau sebesar 2.5 persen. Artinya, indeks kemiskinan absolut rumah tangga mustahik mengalami penurunan sebesar 90.91 persen. Dengan demikian, terbukti bahwa dengan adanya bantuan dana zakat yang diberikan kepada rumah tangga mustahik dapat menurunkan indeks kemiskinan absolut yang terjadi pada rumah tangga mustahik.

\section{KESIMPULAN}

1. Pendapatan rumah tangga mustahik setelah mendapatkan bantuan dana zakat produktif dari Zakat Center Thoriqotul Jannah Cirebon mengalami perubahan yang signifikan. Sebelum adanya bantuan dana zakat, rata-rata pendapatan rumah tangga mustahik adalah Rp 1.110.563,- dan setelah mendapatkan bantuan dana zakat rata-rata pendapatan rumah tangga mustahik naik menjadi Rp. 1.653.000,- 
Islamiconomic: Jurnal Ekonomi Islam Vol.9 No.2 Juli - Desember 2018

Artinya terjadi peningkatan rata-rata pendapatan rumah tangga mustahik sebesar Rp. 542.437,--.

2. Berdasarkan model CIBEST, karakteristik nilai material dan spiritual mustahik setelah mendapatkan bantuan dana zakat produktif dari Zakat Center Thoriqotul Jannah Cirebon mengalami perubahan. Setelah adanya bantuan dana zakat, jumlah rumah tangga mustahik yang berada pada kategori rumah tangga sejahtera (kuadran I) mengalami peningkatan sebesar 47.50 persen. Sedangkan jumlah rumah tangga mustahik yang masuk kategori miskin material (kuadran II) menurun 25.00 persen. Begitupun jumlah rumah tangga mustahik yang masuk kategori miskin spiritual (kuadran III) dan miskin absolut (kuadran IV) masingmasing turun sebesar 54.55 persen dan 90.91 persen.

\section{PUSTAKA ACUAN}

Badan Pusat Statistik [BPS] Provinsi Jawa Barat. 2016. Jumlah Penduduk Miskin dan Garis Kemiskinan Kota/Kab Ciayumajakuning. BPS Jawa Barat. Bandung.

Badan Pusat Statistik [BPS]. 2014. Data Ketenagakerjaan dan Pengangguran. Jakarta.

Beik IS, Arsyianti LD. 2015. Construction of CIBEST Model as Measurement of Poverty and Welfare Indicesfrom Islamic Perspective. Al-iqtishad Vol VII No 1.

Beik IS. 2009. Analisis Peran Zakat dalam Mengurangi Kemiskinan: Studi Kasus Dompet Dhuafa Republika. Jurnal Pemikiran dan Gagasan. Al-iqtishad Vol 2.

Suprayitno, Eko, \& Kawan-Kawan, "The Impact of Zakat on Aggregate Consumption in Malaysia", Journal of Islamic Economics, Banking, and Finance, Vol. 9, No. 1, 2013.

Zakat Center Thoriqotul Jannah Cirebon. 2017. Laporan Pertanggungjawaban Zakat Center Thoriqotul Jannah Cirebon. Cirebon.

\section{Catatan Akhir:}

\footnotetext{
${ }^{1}$ Badan Pusat Statistik (BPS). 2016. Jumlah dan Persentase Penduduk Miskin Indonesia dari tahun 2009 2014. https://www.bps.go.id/. [7 Juli 2017]
} 